\title{
A Biocompatibility Study of a New Root \\ Canal Sealer
}

Tahani A Al- Sandook BDS, MSc, PhD (Prof)

Manar M Al-Nema

BDS, MSc, Prof (Lect)

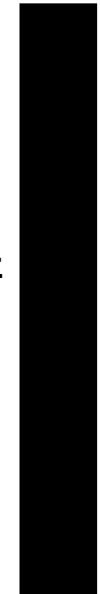

\author{
Department of Basic Dental Sciences \\ College of Dentistry, University of Mosul
}

Department of Oral and Maxillofacial Surgery

College of Dentistry, University of Mosul

\section{Department of Basic Dental Sciences}

College of Dentistry, University of Mosul

Heba
BDS

\section{الخلاصة}

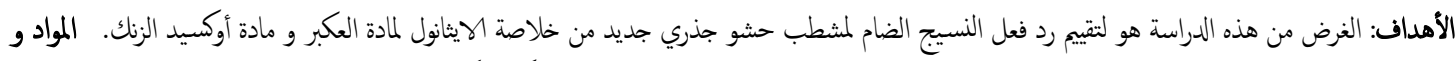

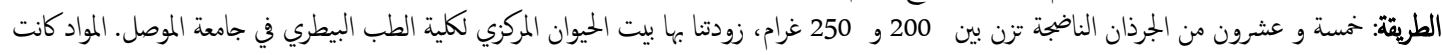

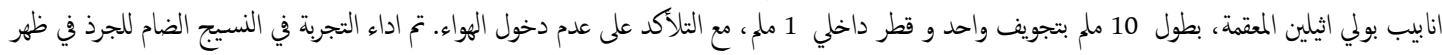

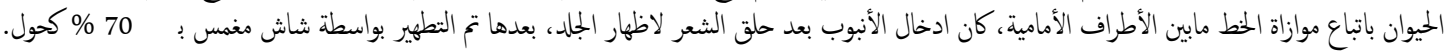

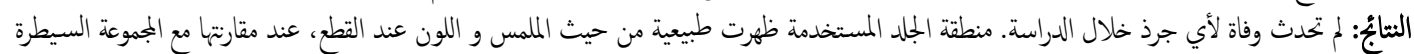

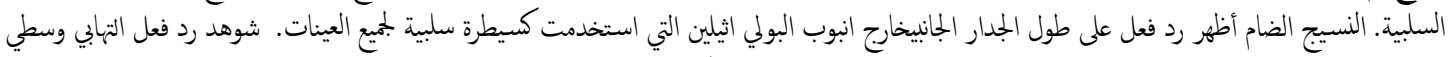

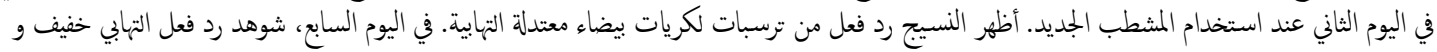

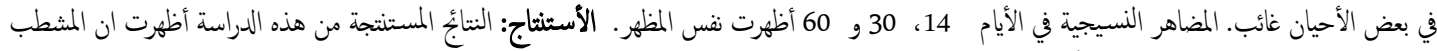

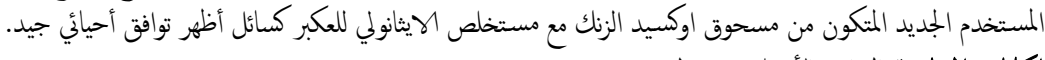

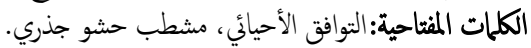

\begin{abstract}
Aims: The purpose of this study was to evaluate the reaction of the subcutaneous connective tissue to a new sealer composed of ethanolic extract of Propolis (EEP) and zinc oxide powder. Materials and Methods: Twenty five adult rats (Rattus novergicus, Albinos wistar) weighting between 200 and 250 grams, provided by central animal house of Mosul University of the Veterinary College were used. Materials were autoclaved polyethylene tubes, $10 \mathrm{~mm}$ long with a single lumen and an inner diameter of $1 \mathrm{~mm}$, ensuring that air was not entrapped. The procedure was preformed in the subcutaneous tissue of the rat in the dorsum of the animal following the sagittal line between the frontal legs, was submitted to trichotomy for exposure of the skin, followed by a sepsis with a gauze soaked with $70 \%$ alcohol. Results: No rats died during the experimental study. The surviving skin appeared normal in this texture and bled when cut, compared to negative control. The connective tissue responded along the lateral wall outside the polyethylene tubes of all specimens also served as a negative control. A moderate inflammatory reaction was observed in the second day when new sealer was used. The tissue reaction showed a focal neutrophilic inflammatory infilterates. On the $7^{\text {th }}$ day a mild to absent inflammatory reaction were observed. The histological features on the 14th, 30th and 60th days showed similar features. Conclusions: The results obtained in the present study allowed the conclusion that the new root canal sealer composed of zinc -oxide (powder) and EEP (liquid) presented good biocompatibility.

Key words: Biocompatibility, root canal sealer.
\end{abstract}

Al- Sandook TA, Al-Nema MM, Hamodat HF. A Biocompatibility Study of a New Root Canal Sealer. Al-Rafidain Dent J. 2010; 10(1):119-126 .

Received: $21 / 7 / 2008 \quad$ Sent to Referees: $21 / 7 / 2007$

Accepted for Publication: 31/12/2008

\section{INTRODUCTION}

Successful endodontic therapy depends on a correct diagnosis, effective cleaning, elimination of infection and obturation of root canals. ${ }^{(1,2)}$ Periapical tissue reaction after root canal treatment may be influenced by various factors depending on the chemical nature of the endodontic sealer. ${ }^{(3)}$ Currently used in clinical practice are resin-, zinc oxide - eugenol, glass ionomer-, silicon-, and calcium hydroxide - based endodontic sealers. ${ }^{(2,4-6)}$

Despite the great variety of sealers available, a root canal sealer that possess 
all the desirable physical and biological properties have yet to be found. ${ }^{(5)}$ Biocompatibility is one of the most important properties of root filling material ${ }^{(7)}$. Since, -the release of certain substances by sealers may generate different reactions in the periapical tissues. $(1-5,8)$ Tissue reactions caused by endodontic materials are normally investigated by histological studies following the implantation of the material into animal tissue. ${ }^{(1,8-10)}$

Propolis is a resinous hive product collected by honeybees from plants, showing a highly complex composition. ${ }^{(11)}$ Propolis has attracted investigators in the last decades because several biological and pharmacological properties, such as immunomodulatory, antitumor, antimicrobial, anti-inflammatory, antioxidant, amo-ng others. ${ }^{(11)}$

Propolis has been used in folk medicine cor centuries. Pharmacological activities such as antimicrobial, anti-inflammatory $\left.^{(12-19}\right)$, anticariogenic and antioxidant ${ }^{(20-25)}$ have been described.

Propolis is safe and shows no side effect after administration. The antimicrobial effect may occur through a direct action on microorganisms and indirectly as well via stimulation of the immune system and further microorganisms killing. Propolis may also show synergistic effects with antimicrobial drugs. ${ }^{(26)}$

The biological activity of propolis is associated mainly with phenolic compounds such as flavonoids and derivatives of cinnanic acids. ${ }^{(27)}$

The biological activities of a zinc oxide — eugenol (ZOE) — based root canal sealers, has been previously studied regarding antibacterial activity ${ }^{(28,29)}$ and tissue biocompatibility ${ }^{(1,3,30)}$

Eugenol (4-allyl-2-methoxyphol) is an extract of clove oil widely used in dentistry as a therapeutic agent, most commonly as a component of zinc oxide-eugenol cement applied as a base or temporary dressing to dentin or as a root canal sealers ${ }^{(8)}$. Several studies have been reported on the histopathologic influence of ZOE -based root canal sealers on tissues(30,31). Eugenol that leaches out of ZOE - based root canal sealers may participate in the development of periapical inflammation or the continuation of a pre- existing periapical lesion. ${ }^{(8)}$

The purpose of this study was to evaluate the reaction of the subcutaneous connective tissue to a new sealer composed of ethanolic extract of propolis (EEP) and zinc oxide powder.

\section{MATERIALS AND METHODS}

Twenty five adult rats (Rattus novergicus, Albinos wistar) weighting between 200 and 250 grams were used. There animals provided by central animal house of Mosul University of the Veterinary College. The animals were subjected to a light/dark cycle of 12 hours, mean temperature of $25^{\circ} \mathrm{C} \pm 3^{\circ} \mathrm{C}$ with a free access to solid chow and water libitum, thus closely preserving their habitual situation. The specimens were divided into five groups, five for each.

The materials were prepared in the manner devised by the manufacturers for the clinical use and loaded into autoclaved polyethylene tubes, $10 \mathrm{~mm}$ long with a single lumen and an inner diameter of I mm, ensuring that air was not entrapped. ${ }^{(32)}$

The surgical procedures were done under general anesthetic drug, after shaving and scrubbing the dorsal area with an antiseptic solution, by intraperitoneal administration of xylazin $3 \mathrm{mg} / \mathrm{kg}$ body weight was given for sedation analgesia, anesthesia and muscle relaxation. This was followed after few minutes with an intraperitoneal injection of $50 \mathrm{mg} / \mathrm{kg}$ ketamine hydrochloride to obtain dissociate anesthesia and this was repeated in every occasion wherever was a reflex. ${ }^{(33,34)}$

The procedure was preformed in the subcutaneous tissue of the rat in the dorsum of the animal following the sagittal line between the frontal legs, was submitted to trichotomy for exposure of the skin, followed by a sepsis with a gauze soaked with $70 \%$ alcohol.

Three straight small incisions approximately $15 \mathrm{~mm}$ long were made with a blade No. 10, on both sides of the dorsum, approximately $5 \mathrm{~cm}$ was between each incision and the each of which was about $1.5 \mathrm{~cm}$ which exposed the subcutaneous connective tissue ${ }^{(35)}$. The margins of the incision were retracted and the connective tissue dissected by a blunt instrument and each animal received six tubes; two con- 
taining the ethanolic extract of propolis (EEP)(zinc oxide powder, Nineva Drug Industry, Iraq with $30 \%$ propolis from Mosul region, Iraq), two contained control positive sealer (zinc oxide eugenol sealer, Dorident, Austria) and two empty for negative control). After implantation, the margins of the wound were joined and closed with interrupted suture (4.0 black silk suture). Sacrifice of the groups was in accordance to the time periods 2 days, 1 week, 2 weeks, 1 month and 2 months. The method of euthanasia was exsanguinations by decapitation. ${ }^{(36)}$

The specimens were stained with hematoxylin and eosin after histopathological techniques.

\section{RESULTS}

The interpretation of the results were based on the following FDI criteria ${ }^{(12)}$ : no or slight reaction at all time periods is ac- ceptable; no to slight reaction at 2 weeks that increased to moderate or severe reaction at 2 months is not acceptable; moderate reactions at 2 weeks and 2 months is unacceptable; moderate reaction at 2 weeks that diminishes at 2 months is acceptable; and a severe reaction at any period is unacceptable.

\section{Macroscopic findings:}

No rats died during the experimental study. The skin of surviving rats appeared normal in these textures and bled when cut.

\section{Microscopic findings:}

The connective tissue adjacent to the open end of the polyethylene tube was evaluated and a descriptive analysis of the histologic findings was made and compared to control negative. The data obtained are summarized in Table (1) and Figures $(1-4)$.

Table (1): Number of samples in each inflammatory category at different time from for the two types of sealers.

\begin{tabular}{|c|c|c|c|c|c|}
\hline Sealer & $\begin{array}{l}\text { Experimental pe- } \\
\text { riods (day)s }\end{array}$ & No. & $\begin{array}{l}\text { Non to } \\
\text { slight }\end{array}$ & Moderate & Severe \\
\hline \multirow{5}{*}{ Experimental (new sealer) } & 2 & 5 & & 5 & \\
\hline & 7 & 5 & 5 & & \\
\hline & 14 & 5 & 5 & & \\
\hline & 30 & 5 & 5 & & \\
\hline & 60 & 5 & 5 & & \\
\hline \multirow{4}{*}{$\begin{array}{l}\text { Control positive zinc oxide } \\
\text { with eugenol sealer }\end{array}$} & 2 & 5 & & & 5 \\
\hline & 7 & 5 & & & 5 \\
\hline & 14 & 5 & & 5 & \\
\hline & 30 & 5 & & 5 & \\
\hline \multirow{6}{*}{$\begin{array}{c}\text { Control negative (empty } \\
\text { tube) }\end{array}$} & 60 & 5 & 5 & & \\
\hline & 2 & 5 & & & 5 \\
\hline & 7 & 5 & & 5 & \\
\hline & 14 & 5 & 5 & & \\
\hline & 30 & 5 & 5 & & \\
\hline & 60 & 5 & 5 & & \\
\hline
\end{tabular}




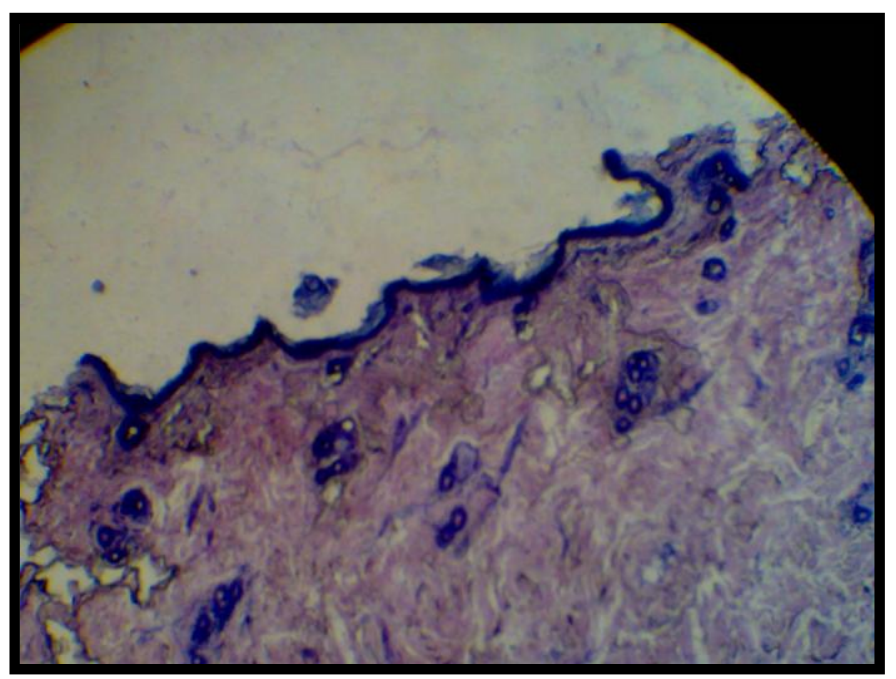

Figure (1): Microscopical view of second day period.

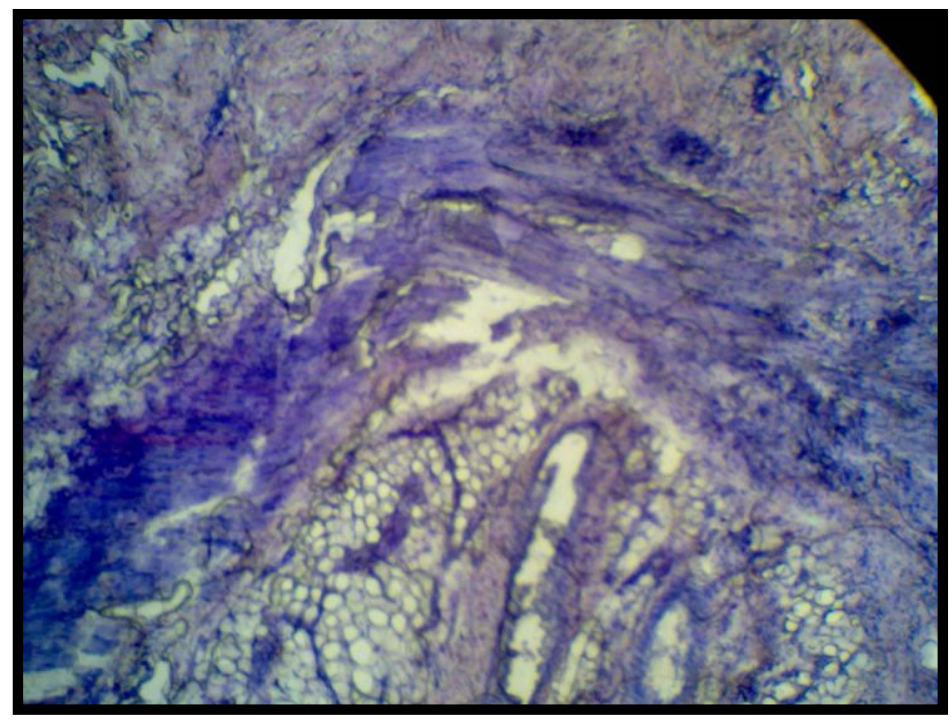

Figure (2): Microscopical view of $14^{\text {th }}$ days period.

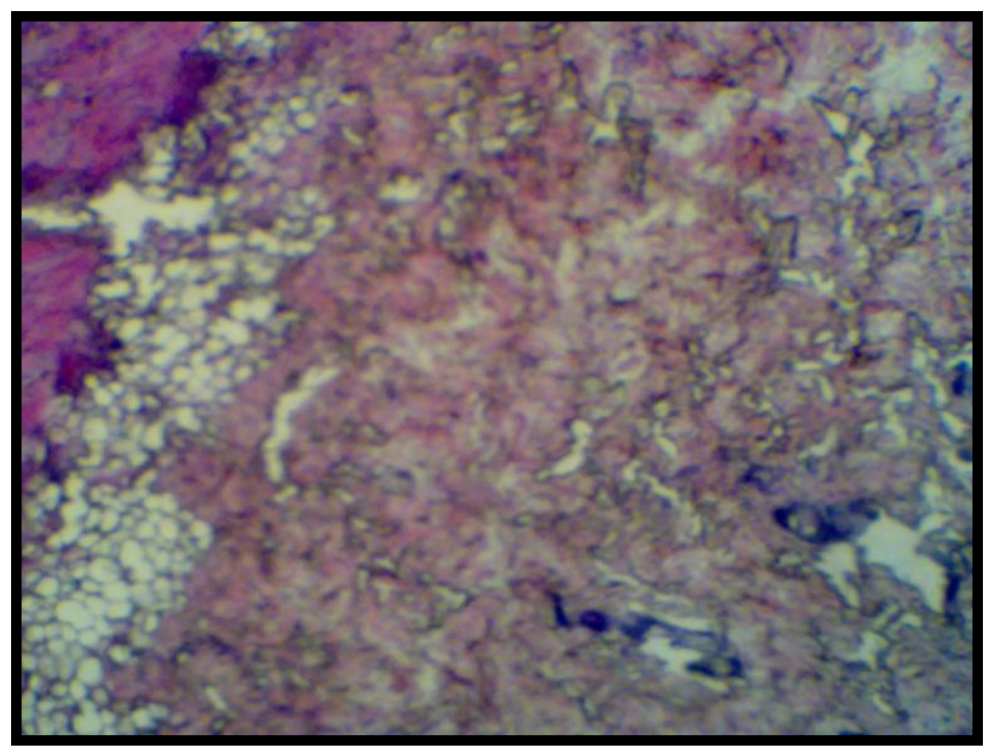

Figure (3): Microscopical view of $30^{\text {th }}$ days period. 


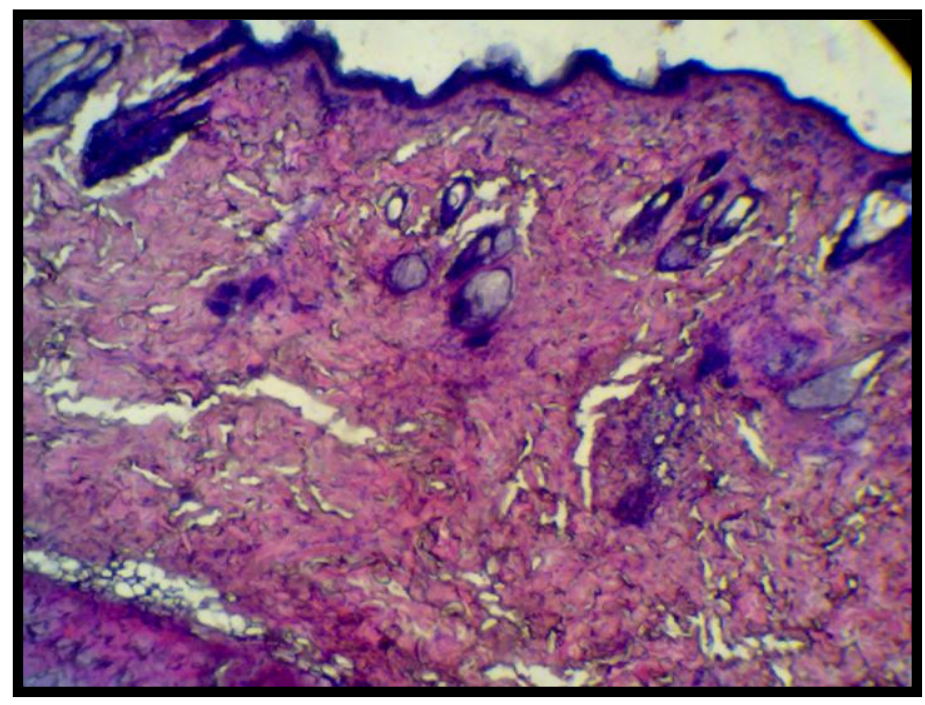

Figure (4): Microscopical view of $60{ }^{\text {th }}$ days period.

\section{The new sealer:}

On the second day, a moderate inflammatory reaction was observed. The tissue reaction showed a focal neutrophilic inflammatory infiltrates. On the $7^{\text {th }}$ day a mild to absent inflammatory reaction and no changes were observed. The histological features on the $14^{\text {th }}, 30^{\text {th }}$ and $60^{\text {th }}$ days showed similar features.

Zinc oxide eugenol sealer:

On the second day period, a severe acute inflammatory reaction was observed, as neutrophils were intense. In the $7^{\text {th }}$ day period, the inflammatory reaction composed of severe chronic inflammatory reaction, with a predominant lymphocyte infiltration and mononuclear leucocytes. The $14^{\text {th }}$ day period showed a moderate chronic inflammatory reaction, with infiltration of lymphocytes and a few multinucleated giant cells were observed. The $30^{\text {th }}$ day period also revealed a moderate chronic inflammatory reaction with lymphocytes being the predominant inflammatory cells. The $60^{\text {th }}$ day period showed reduction of the inflammatory reaction to become mild with few chronic inflammatory infiltrates.

\section{The control negative:}

The second day period showed histological features of a severe acute inflammatory reaction with a healthy neutrophil infilteration. The $7^{\text {th }}$ day period revealed a moderate chronic inflammatory reaction with lymphocytes and few neutrophils infiltera- tion. The $14^{\text {th }}, 30^{\text {th }}$ and $60^{\text {th }}$ days periods revealed a mild to slight chronic inflammatory reaction.

\section{DISCUSSION}

The subcutaneous connective tissue implantation in animals is one of the most reliable methods of evaluating biocompatibility of dental material ${ }^{(4,7,37,38)}$, because inflammatory reactions are characteristic features for all connective tissues $^{(7,38)}$.

Overall level of the tissue reaction was rated as none, slight, moderate, or severe depending on the presence or absence of neutrophils leukocytes, macrophages, lymphocytes, plasma cells, giant cells, dispersed material and necrotic tissue, according to Federation Dentaire International (FDI) ${ }^{(39)}$

In the present study, the subcutaneous tissue inflammatory reaction to the ZOE sealer was severe, but then devreased with time after the 7 day period, similarly to the results obtained by Kaplan et al.(3), probably owing to the neutralization of the eugenol librated at the stat ${ }^{(10,40,41)}$. Many investigators have suggested that the irritative ability of ZOE - based sealers could be attributed primarily to eugenol and secondarily to zinc ions ${ }^{(4,42-45)}$.

Biocompatibility effect of a new root canal sealer revealed an acceptable biological property where non to slight inflammation reactions established on day 
$7,14,30$ compared to moderate and severe in ZOE and similar to the control in accordance with Alnema $(2006)^{(19)}$ which explain the powerful anti-inflammatory activity of propolis.

In spite of the good biocompatible results obtained in most groups and as this is the first study to deal with this new root canal sealer, further study is required to fully assess the biological response of this new sealer.

\section{CONCLUSIONS}

According to FDI criteria, the results obtained in the present study allowed the conclusion that the new root canal sealer composed of the zinc -oxide (powder) and EEP (liquid) presented biocompatibility within the analyzed periods.

\section{REFERENCES}

1. Bernath M, Szabo J. Tissue reaction initiated by different sealers. Int. Endod. J. 2003; 36: $256-261$.

2. Bouillaguet S, Wataha JC, Lockwood PE, Galgano C, Golay A, Krejci I. Cytotoxicity ans sealing properties of four classas of endodontic sealers evaluated by succinic dehydrogenase activity and confocal laser scanning microscopy. Eur. J Oral Sci. 2004; 112: $182-187$.

3. Kaplan AE, Ormaechea MF, Picca M, Canzobre MC, Ubios AM. Rheological properties and biocompatibility of endodontic sealers. Int. Endod. J.; 2003; 36: $527-532$.

4. Hauman CH, Love RM. Biocompatibility of dental materials used in contemporary endodontic therapy: a review. Part 2. Root - canal - filling materials. Int. Endod. J.2003; 36: 147 - 160 .

5. Gençoĝlu N, Turkmen C, Ahiskali R. A new silicon - based root canal sealer (Roekoseal -Automix). J. Oral Rehabil. 2003; 30: 753 - 757.

6. Zmener $\mathrm{O}$, Banegas $\mathrm{G}$, Pameijer $\mathrm{CH}$. Bone tissue response to a methacrylate - based endodontic sealer: a histological and histometric study. J. Endod.2005; 31: 457 - 459 .

7. Ozbas H, Yalyirik M, Bilgic B, Issever H. Reactions of connective tissue to compomers, composite and amalgam root end filling materials. Int. Endod. J.
2003; 36: $281-287$.

8. Ho YC, Huang FM, Chang YC. Mechanisms of cytotoxicity of eugenol in human osteoblastic cells in vitro. Int. Endod. J. 2006; 39: 389-393.

9. Hauman $\mathrm{CH}$, Love RM. Biocompatibility of dental materials used in contemporary endodontic therapy: a review. Part 1. Intracanal drugs and substances. Int. Endod. J. 2003; 36: 75 - 85 .

10.Sousa CJ, Loyola AM, Versiani MA, Biffi JC, Oliveira RP, Pascon EA. A comparative histological evaluation of the biocompatibility of materials used in apical surgery. Int. Endod. J. 2004; 37: $738-748$.

11.Bankova VS, Castro SL, Marcucci MC. Propolis: recent advances in chemistry and plant origin. Apidologie. 2000; 31: 3 -15 .

12.Khayyal MT, Elghazaly MA, Elkhatib AS. Mechanisms involved in the antiinflammatory effect of propolis extract. Drugs under Experimental and Clinical Research. 1993; 19: 197 - 203.

13.Park YK, Koo MH, IKegaki M, Cury JA, Rosalen PL, Abreu JAS. Antimicrobial activity of propolis on oral microorganisms. Current Microbiology. 1998; 36: $24-28$.

14. Koo H, Rosalen PL, Cury JA, Ambrosano GMB, Murata RM, Yatsuda R, Ikegaki M, Alencar SM, Park YK. Effect of a new variety of Apis mellifera propolis on mutants streptococci. Current Microbiology. 2000; 41: 192 - 196.

15.Koo H, Smith AMV, Bowen WH, Rosalen PL, Cury JA, Park YK. Effect of Apis mellifera propolis on the activities of streptococcal glucosyltransferase in solution and adsorbed onto saliva coated hydroxyapatite. Caries Res. 2000; 34: 418 - 426.

16.Duarte S, Koo H, Bowen WH, Hayacibara MF, Cury JA, Ikegaki M, Park YK, Rosalen PL. Effect of a novel type of propolis and its chemical fractions on glucosyltransferases and on growth and adherence of mutans streptococci. Biological and Pharmaceutical Bulletin. 2003; 26: 527 - 531.

17.Duarte S, Rosalen PL, Hayacibara MF, Cury JA, Bowen WH, Marquis RE, Rehder VLG, Sartoratto A, Ikegaki M, Koo $\mathrm{H}$. The influence of a novel propolis 
on mutans streptococci biofilms and caries development in rats. Arch. Oral Biol. 2006; 51: $15-22$.

18. Hayacibara MF, Koo H, Rosalen PL, Duarte S, Franco EM, Bowen WH, Ikegaki M, Cury JA. In vitro and in vivo effects of isolated fractions of Brazilian propolis on caries development. J. Ethnopharmacology. 2005; 101: $371-376$.

19. Alnema MM. An analytical and histological study of a new root canal filling material composed of Iraqi propolis, beeswax and vanillin. Ph.D. Thesis, College of Dentistry, University of Baghdad. 2006.

20.Burdock GA. Review of the biological properties and toxicity of bee propolis. Food and Chemical Toxicology. 1998; 36: 347 - 363 .

21.Chen CN, Wu CL, Shy HS, Lin JK. Cytotoxic prenylflavanones from Taiwanese propolis. J. Natural Products. 2003; 66: 503 - 506.

22.Nagai T, Inue R, Inoue H, Suzuki N. Preparation and antioxidant properties of water extract of propolis. Food Chemistry. 2003; 80: $29-33$.

23. Aso K, Kanno SI, Tadano T, Satoh S, Ishikawa M. Inhibitory effect of propolis on the growth of human leukemia U937. Biological and Pharmaceutical Bulletin. 2004; 27: 727 - 730.

24.Ishikawa M, Kanno S, Asou K, Ogino M, Tadano T, Satou S. Inhibition of growth and induction of apoptosis in human cancer cell lines by propolis. J. Pharam. Sci. 2004; 94: 129.

25.Kumazawa S, Harnasaka T, Nakayama T. Antioxidant activity of propolis of various geographic origins. Food Chemistry. 2004; 84: 329-339.

26. Sforcin JM. Propolis and the immune system: a review. J. Ethnopharacology. 2007; 113: $1-14$.

27.Castro SL. Propolis: biological and pharmacological activities. Therapeutic uses of this bee -product. Ann. Rev. Biomed. Sci. 2001; 3: 49-83.

28.Gomes BP, Pedroso JA, Jacinto RC, Vianna ME, Ferran CC, Zaia AA, et al. In vitro evaluation of the antimicrobial activity of 5 root canal sealers. Bran. Dent. J. 2004: 15: 30 - 35.

29.Pizzo G., Giammanco GM, Cumbo E, Nicolosi G, Gallin ${ }^{\mathrm{g}} \mathrm{G}$. In vitro antibac- terial activity of endodontic sealers. $J$ Dent. 2006; 34: 35 -40.

30.Tepel J, Darwisch SM, Hoppe W. Reaction of inflamed periapical tissue to intracanal medicaments and root canal sealers. Endod. Dent. Traumatol. 1994; 10: $233-238$.

31.Holland R, Otoboni Filho JA, Bernabe PF, Nery MJ, de Souza V, Berbert A. Effect of root canal status on periodontal healing after surgical injury in dogs. Endod. Dent. Traumatol. 1994; 10: 77 - 82.

32.Campos -Pinto MMD, Oliveira DA, Versiani MA, Silva-Sousa YTC, Sousa Neto MD, Cruz-Perez DE, Preto R. Assessment of the biocompatibility of epiphany root canal sealer in rat subcutaneous tissues. Oral Sung. Oral Med. Oral Pathol. Oral Radiol. Endod. 2008; 105: e77 - e81.

33. Aydogan H, Gurlek A, Parlakpinar H, Askar I, Bay -Karabulut A, Aydogan N, Fariz A, Acet A. Beneficial effects of caffeic acid phenethyl ester (CAPE) on the ischaemia -reperfusion injury in rat skin flaps. J Plastic, Reconstructive \& Aesthetic Surgery. 2007; 60: 563-568.

34.Semenoff ADV, Segundo AS, Figueiredo JAP. Biocompatibility of different intracanal medications in rat buccal submucosa tissue. J. Appl. Oral Sci. 2008; 16(1): $12-17$.

35. Marquele -Oliveira F, Fonseca YM, de Freitas 0, Fonseca MJV. Development of topical functionalized formulations added with propolis extract: stability, cutaneous absorption and in vivo studies. Int. J Pharmac. 2007; 342: 40 - 48.

36.Sforcin JM, Funari SRC, Novelli ELB. Serum biochemical determinations of propolis - treated rats. J. Venomous Animals and Toxins. 1995; 1:31 - 37.

37. Stanley HR. Toxicity of dental materials. $1^{\text {st }}$ edition. Miami: CRC Press; 1985.

38. Olson B, Sliwkowski A, Langeland K. Subcutaneous implantation for the biological evaluation of endodontic materials. J. Endod. 1981; 7: 355 - 367.

39.Federation Dentaire International, Commission of Dental Materials, Instruments, Equipment and Therapeutics. Recommended standard practices for biological evaluation of dental materials. Int. Dent. J. 1980; 30: 140 - 188 .

40.Hume WR. Effect of eugenol on respira- 
tion and division on human pulp, mouse fibroblasts and liver cells in vitro. $J$. Dent. Res. 1984; 63: 1262-1265.

41.Gulati N, Chandra S, Aggarwal PK, Jaiswal JN, Singh M. Cytotoxicity of eugenol in sealer containing zonc -oxide. Endod Dent. Traumatol. 1991; 7: 181 185.

42.Schwarze T, Fiedler I, Leyhausen G, Geurtsen W. The cellular compatibility of five endodontic sealers during the setting period. $J$ Endod. 2002; 28: 784 786.

43.Neff T, Layman D, Jeansonne BG. In vitro cytotoxicity evaluation of endodontic sealers exposed to heat before assay. $J$ Endod. 2002; 28: 811-814.

44.Ioannis K, Nikolaos E. In vivo comparison of the biocompatibility of 2 root canal sealers implanted into the subcutaneous connective tissue of rats. $J$ Endod. 1998; 24: $82-85$.

45.Nikolaos E, Ioannis K. Experimental study of the biocompatibility of four root canal sealers and their influence on the zinc and calcium content of several tissues. J Endod. 1995; 21: $122-127$. 